\title{
Patron Attitudes Towards Modern Banking Services and Innovation in Virudhunagar District
}

\author{
J Srinivasan, R Deepika, M Selva Kumar
}

\begin{abstract}
Attitudes are a vital idea in reading customer behavior. This work has explored the customer elements to shape various attitudes in the direction of incomparable banks located in Virudhunagar. From the perception of consumer, credible solutions can be discovered. The service quality of Virudhunagar banks can be expanded by considering the effectual quality service dimensions of customers. This has closing survival within the banking area of Virudhunagar which may be very dynamic and competitive. The survey is conducted for 150 participants by a sampling technique. The overall ability markets picture can be found by measuring customer's attitudes which would be a support for provider marketer. The provider markets always look for the attitudes which plays a vital role in identifying purchaser's discriminating methods, gaining knowledge and the shopping conduct. The reason for this study is to examine the attitude of the service of the banks by performing employee assessment as well as customer acuity of banks in Virudhunagar district. A reflection of service quality of organizational overall performance is called the ultimate degree of satisfaction of customer which keeps customers for life. Attitudes are predisposed reactions to an item.
\end{abstract}

Keywords: Service Quality, Attitude, Banking Sector, Customer Perception.

\section{INTRODUCTION}

People make use of the services of the banks to meet up their range of purposes. Hence the provision of incredible provider should be prioritized by a banking employer to its customers. Services delivered by way of the banks play a necessary function by informing the customer's attitude closer to the organizations. The banking industry is a service industry. Currently, there are many banks in Virudhunagar. Measuring client attitude has come to be a buzzword in the modern-day business world. In the current scenario, the consumer's attitude has ended up a necessary region for commercial banks. This will assist to acquire an advantageous attitude from customers. It offers its customers a range of economic services.

In the last few years, there has been a vast improvement in number of banks has gone through the competitive sector from banking sector in Virudhunagar district in which each financial institution is trying to obtain the maximum share in the market. The countries financial realm can be uplifted by the pivotal position of the banks by means of affording an

Revised Manuscript Received on September 10, 2019.

J Srinivasan, Assistant Professor in Commerce, Sri Krishna Arts and Science College, Coimbatore, Tamilnadu, India.

(E-mail: patelnirzari84@gmail.com)

R Deepika, Assistant Professor in Commerce, Sri Krishna Arts and Science College, Coimbatore,Tamilnadu,India.

(E-mail: m.p.barot@gmail.com)

Dr. M Selva Kumar, Associate Professor in Commerce, Ayya Nadar Janaki Ammal College, Sivakasi, Tamilnadu, India.

(E-mail: patelnirzari84@gmail.com) economic communications in the sector offerings. Due to the evolution of new economic products and horizon of services has brought an incredible boom in the Virudhunagar banking area.

Studies additionally expose that excessive customer delight also leads to the excessive profitability of the organization. In this perspective, consumer grasp related to the carrier quality of the financial institution is very important. The customers are satisfied with the quality of service. The recital and success of any organization is dependent upon the satisfaction of customer.

Nowadays the area and the technique of banking are rapidly getting wider and quickly spreading. The survey deals with the examining the attitude of consumer in the direction of banks. The monetary carrier providers are banks, public cash can be administered and executing the number of great roles in the financial system of any country. This is useful for banks to locate the customer attitudes based on the services. In Virudhunagar, various private banks are running their things to do for a long time. They are taking part in an imperative role in satisfying the customer needs by enhancing the banking services in the country. With the help of commercial banks it exhibits the issues and also tries to discover eminent solutions to conquer these difficulties.

\section{RELATED WORK}

A. Palani, P Y (2012) has made a research in Indian Overseas bank located in Chennai towards customer awareness about mobile banking. It always focuses on the parameters associated with perception of customers. The author found that the users are facing numerous troubles with handset, software program, and Telecom operator for using the services. The reasons are analyzed and corrections are examined by the invention of mobile banking. His research, carried out to affirm the version of mobile banking. The discovery of mobile banking has made more cost effective in banking.

Considering the self idea of the customer by assessing the consumer behavior and it is proposed by Assael (1981). The attitude may be changing according to the customer and developed by mastering technique. The affecting characteristics are identified by organization by introducing the liking or disliking scale.

Yong (2000) determined the carrier definitions and afforded these styles of provider that are essential in recognizing the exceptional service concept.

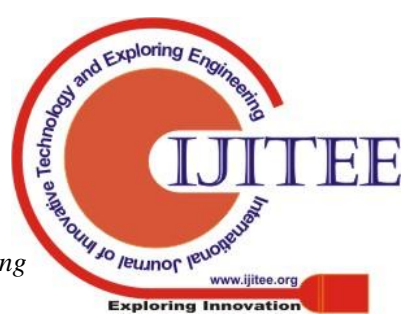


He determined that there's a fantastic association between exceptional attributes and customers' delight, primarily in Bangladesh and additionally supported a comparative look at Islamic and conventional banks in Pakistan. This can be developed by customer interaction and service suppliers. Another method is analyzing the customer requirements. Service quality is an essential and emergent approach within the advertising and it offers a robust foundation to maintain aggressive function and marketplace proportion.

\section{CUSTOMER PERCEPTION OVER THE DECADES}

There is an out of the ordinary exchange and paradigm shift closer to customer focal point over the previous five decades. The list of channels is established among the customer and provider to have (i) Direct communication (ii) Communicating through phone (iii) email communication etc. The customer's perceptions are the pillars of banks and the problems are analyzed on the basis of primacy. This is aimed not only to the existing customer from taking their commercial enterprise somewhere else however also to make sure that they are presented the product and services that are most fabulous all likelihood to result in new income for the bank.

\section{PROBLEM STATEMENT}

The present customer services structures lack motivation and tasks; those adversely have an effect on customer support. This results in frustration among customers. In Virudhunagar, there is various banks that had been functioning. The cheque book issuing takes about 20 to 30 minutes because the bank officers are always working with registers, vouchers, cheque updation and these processes tales more time. The investigator has chosen this subject matter to analyze the troubles of public regions and affording the services of the banks. The troubles are

1) Unusual delays in obtaining

2) Payment promotion

3) The waiting line of the customers at the counter is more.

\section{OBJECTIVE OF THE STUDY}

\subsection{Primary Objectives}

-To determine the working conditions of public sector banks located at Virudhunagar city.

-To analyze the quality services of the customer and novel banking technologies.

\subsection{Secondary Objectives}

-To validate the pleasure of the customer through banks those are closer to the services given.

- To scrutinize the troubles regarding the banking transactions.

-To recommend an appropriate counteractive measure to enhance their banking services.

\section{IMPORTANCE AND NEED OF THE STUDY}

Customers of the financial institution moved consistent with the technology because of their busy schedule in their

works. During non-availability of the banking carrier in vacations, they may be transferred toward the internet services or different retailers to switch the quantity for his or her cause, where the mobile banking allows them to transfer and do all the activities in the identical vicinity without shifting anywhere. Based on the attitude of the customer there's an exchange in the behavior banking manner with the help of mobile banking that's extra at ease. New generation makes the change in the conventional processing of the Bank works. Banks that are started out to increase their activities with the help of new banking products like ATM, mobile banking, tele banking, net banking and digital fund transfer which is successfully used by the clients.

\section{RESEARCH GAP}

Even though the banking sectors are involved in innovative banking services, the customers have more confusion in choosing the best banking service. The gap with respect to socio economic attribute tells the significant difference towards various banking products.

\section{NEW TECHNOLOGY SERVICES}

\subsection{ATM}

Automatic teller Machine (ATMs) is the plastic cards for cash withdrawal. The authentication can be provided by giving a private identification number (PIN) and it is a digital telecommunications system. The transactions like cash deposit and withdrawal can be performed by the customers without any bank staff involvement. With the help of ATM, the deposit can be accessed by the customers and the mobile phone credits as well as balance checking can also be determined.

\subsection{Tele Banking}

Tele banking is the manner of dealing with bank bills over the smartphone. The financial institution offers these types of banking services and the monetary transactions can be enabled by different sectors through telephone without any assistance from the ATM or bank.

\subsection{Mobile Banking}

The customers will be able to supervise their account details, money transfer and check deposits by this service. The services can be kept in control by customers with the help of Mobile banking.

\subsection{Electronic Funds Transfer}

The money can be moved from one account to other account by Electronic Funds. The EFT advantages include reduced administrative costs, extended efficiency, and more security.

\subsection{Internet Banking}

Internet banking is considered to be a vital zone in the finance industry. It gives a platform for the society, as they could check their account information, make payments and transfer money between accounts within a span of time. 


\section{HYPOTHESIS OF THE STUDY}

H0: There is no significant difference between age and attitude towards new banking products.

H1: There is significant difference between age and attitude towards innovative banking products.

\section{METHODOLOGY \& RESULTS}

The data collection procedures have been examined with the SPSS tools. The tools can be used to experiment the hypothesis:

1) Multivariate tests and

2) ROC analysis.

The primary and secondary data are covered in this study. The well designed questionnaire and interviewing technique are used for primary data collection. The Virudhunagar district banks are chosen for this research. The secondary data was gathered from journals and web portals.

The Likert scale ranging is defined as satisfied, neutral and not satisfied and it is measured in table 1 and figure 1 .

\begin{tabular}{|l|l|l|l|}
\hline S.No & $\begin{array}{l}\text { Scaling } \\
\text { Parameters }\end{array}$ & $\begin{array}{l}\text { No of } \\
\text { Respondents }\end{array}$ & Percentage \\
\hline 1 & Satisfied & 84 & $56 \%$ \\
\hline 2 & Neutral & 28 & $18.7 \%$ \\
\hline 3 & Not satisfied & 38 & $25.3 \%$ \\
\hline
\end{tabular}

Table No: 1 Respondents - Scaling Parameters

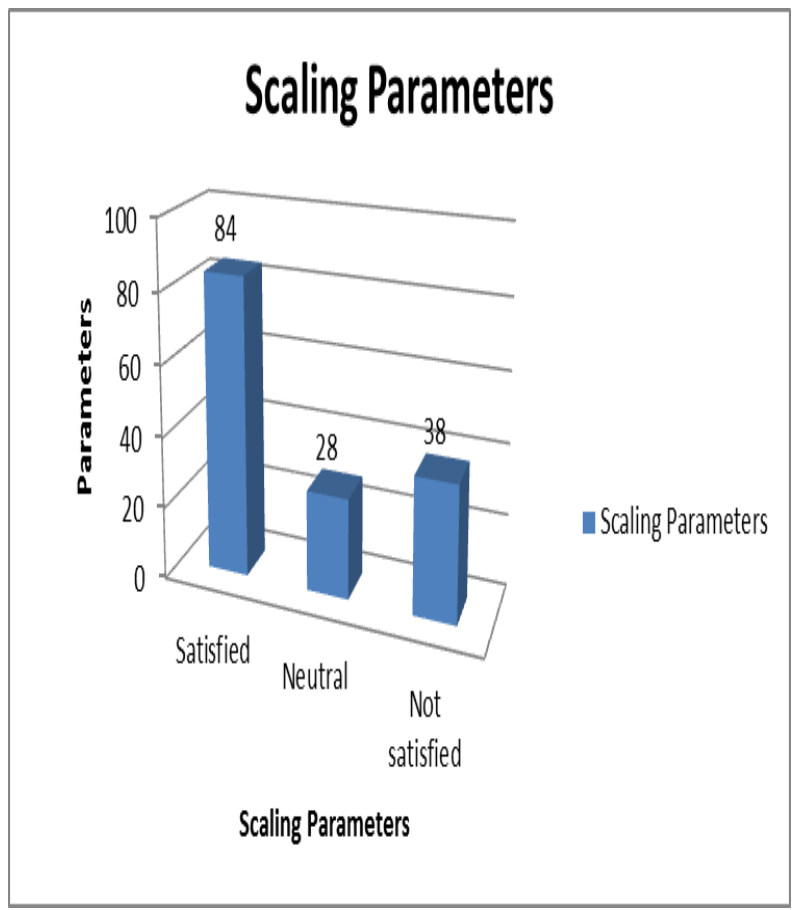

Figure No: 1 Respondents - Scaling Parameters

The above table depicts that $56 \%$ of the respondents are satisfied, $18.7 \%$ of the respondents are neutral and $25.3 \%$ of the respondents are not satisfied.

The difficulties of the customers are found and the mentioned services will help the customers. The table 2 and figure 2 gives the numbers of users who are using the new innovation services.

\begin{tabular}{|l|l|l|l|}
\hline S.No & $\begin{array}{l}\text { Banking } \\
\text { Services }\end{array}$ & $\begin{array}{l}\text { No of } \\
\text { Respondents }\end{array}$ & Percentage \\
\hline 1 & ATM & 80 & $53.33 \%$ \\
\hline 2 & Tele Banking & 3 & $2 \%$ \\
\hline 3 & $\begin{array}{l}\text { Mobile } \\
\text { Banking }\end{array}$ & 10 & $6.67 \%$ \\
\hline 4 & $\begin{array}{l}\text { Electronic } \\
\text { Fund Transfer }\end{array}$ & 7 & $4.67 \%$ \\
\hline 5 & $\begin{array}{l}\text { Internet } \\
\text { Banking }\end{array}$ & 50 & $33.33 \%$ \\
\hline
\end{tabular}

Table No: 2 New Technology Banking Services

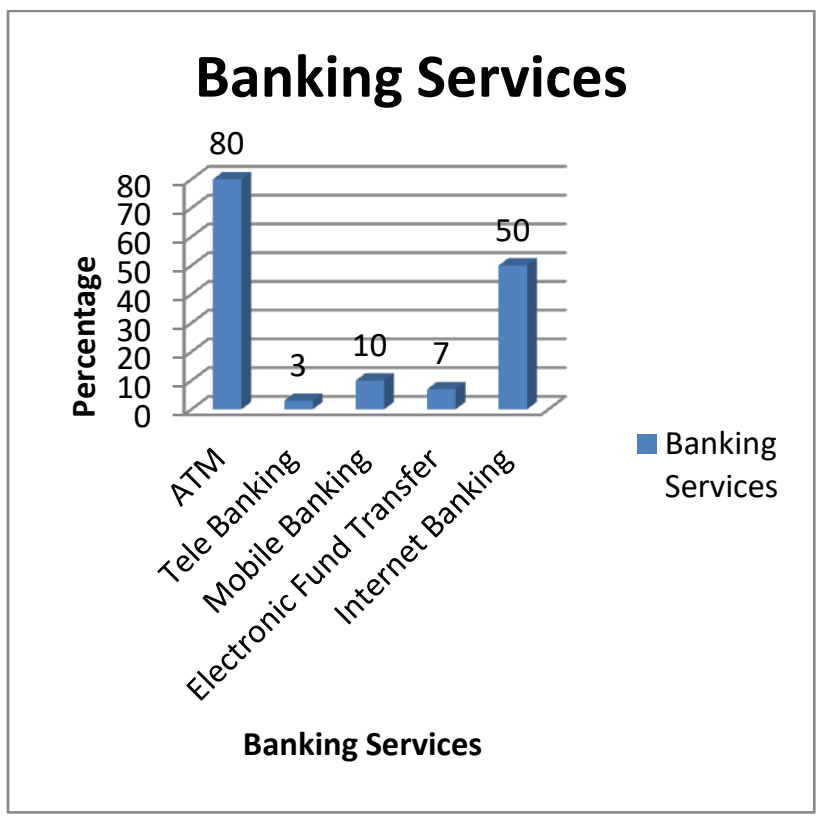

Figure No: 2 New Technology Banking Services

The above table tells that the various new technology banking services are used by the respondents. $53.33 \%$ respondents are availing the ATM service, $2 \%$ respondents are using the tele banking service, $6.67 \%$ are using the mobile banking service, $4.67 \%$ are using the electronic fund transfer and $33.33 \%$ are using the internet banking services.

The following table shows the age and the attitude towards new banking products. It is given in table 3, and table 4.

\begin{tabular}{|l|l|l|}
\hline S.No & Age & $\begin{array}{l}\text { No of } \\
\text { respondents }\end{array}$ \\
\hline 1 & $\begin{array}{l}\text { Below 20 } \\
\text { Years }\end{array}$ & 46 \\
\hline 2 & $20-30$ Years & 9 \\
\hline 3 & $30-40$ Years & 31 \\
\hline 4 & $40-50$ Years & 42 \\
\hline 5 & $50-60$ Years & 18 \\
\hline 6 & $\begin{array}{l}\text { Above } 60 \\
\text { Years }\end{array}$ & 4 \\
\hline
\end{tabular}

Table No: 3 Age of the Respondents

The multivariate tests are used to solve the multi testing problems. The overall test incorporates the correlation among the variables. If the overall test is statistically 
significant then the two groups differ on at least one variable.

\begin{tabular}{|c|c|c|c|c|c|c|}
\hline Effect & $\begin{array}{l}\text { Variab } \\
\text { les }\end{array}$ & $\begin{array}{l}\text { Val } \\
\text { ue }\end{array}$ & $\mathbf{F}$ & dF & $\begin{array}{l}\text { Erro } \\
\text { r dF }\end{array}$ & $\begin{array}{l}\text { Signific } \\
\text { ant } \\
\text { Value }\end{array}$ \\
\hline \multirow{4}{*}{$\begin{array}{l}\text { Interc } \\
\text { ept }\end{array}$} & $\begin{array}{l}\text { Pillai's } \\
\text { Trace }\end{array}$ & $\begin{array}{l}0.96 \\
5\end{array}$ & $\begin{array}{l}2.000 \\
\text { E3 }\end{array}$ & $\begin{array}{l}2.00 \\
0\end{array}$ & $\begin{array}{l}143.0 \\
00\end{array}$ & 0.000 \\
\hline & $\begin{array}{l}\text { Wilks } \\
\text { Lamba } \\
\text { da }\end{array}$ & $\begin{array}{l}0.03 \\
5\end{array}$ & $\begin{array}{l}2.000 \\
\text { E3 }\end{array}$ & $\begin{array}{l}2.00 \\
0\end{array}$ & $\begin{array}{l}143.0 \\
00\end{array}$ & 0.000 \\
\hline & $\begin{array}{l}\text { Hotelli } \\
\text { ng's } \\
\text { Trace }\end{array}$ & $\begin{array}{l}27.9 \\
65\end{array}$ & $\begin{array}{l}2.000 \\
\text { E3 }\end{array}$ & $\begin{array}{l}2.00 \\
0\end{array}$ & $\begin{array}{l}143.0 \\
00\end{array}$ & 0.000 \\
\hline & $\begin{array}{l}\text { Roy's } \\
\text { Largest } \\
\text { Root }\end{array}$ & $\begin{array}{l}27.9 \\
65\end{array}$ & $\begin{array}{l}2.000 \\
\text { E3 }\end{array}$ & $\begin{array}{l}2.00 \\
0\end{array}$ & $\begin{array}{l}143.0 \\
00\end{array}$ & 0.000 \\
\hline \multirow{4}{*}{ Age } & $\begin{array}{l}\text { Pillai’s } \\
\text { Trace }\end{array}$ & $\begin{array}{l}0.78 \\
9\end{array}$ & $\begin{array}{l}18.77 \\
8\end{array}$ & $\begin{array}{l}10.0 \\
00\end{array}$ & $\begin{array}{l}288.0 \\
00\end{array}$ & 0.000 \\
\hline & $\begin{array}{l}\text { Wilks } \\
\text { Lamba } \\
\text { da }\end{array}$ & $\begin{array}{l}0.33 \\
1\end{array}$ & $\begin{array}{l}21.07 \\
8\end{array}$ & $\begin{array}{l}10.0 \\
00\end{array}$ & $\begin{array}{l}286.0 \\
00\end{array}$ & 0.000 \\
\hline & $\begin{array}{l}\text { Hotelli } \\
\text { ng's } \\
\text { Trace }\end{array}$ & $\begin{array}{l}1.65 \\
3\end{array}$ & $\begin{array}{l}23.46 \\
8\end{array}$ & $\begin{array}{l}10.0 \\
00\end{array}$ & $\begin{array}{l}284.0 \\
00\end{array}$ & 0.000 \\
\hline & $\begin{array}{l}\text { Roy's } \\
\text { Largest } \\
\text { Root }\end{array}$ & $\begin{array}{l}1.39 \\
1\end{array}$ & $\begin{array}{l}40.04 \\
9\end{array}$ & $\begin{array}{l}5.00 \\
0\end{array}$ & $\begin{array}{l}144.0 \\
00\end{array}$ & 0.000 \\
\hline
\end{tabular}

Table No: 4 Multivariate Tests

The obtained significant value is 0.000 which is lesser than 0.05 and hence the Null Hypothesis is rejected and the alternative hypothesis is accepted where there is significant difference between age group and attitude towards new banking products. It is confirmed that younger people below the age group of 20 years old have higher attitude towards new banking services than older people by multivariate tests.

The ROC curve is determined for the factors like tangibility, reliability, responsiveness, assurance, empathy, efficiency, accuracy and security.

\begin{tabular}{|l|l|}
\hline Variables & Area \\
\hline Tangibility & 0.555 \\
\hline Reliability & 0.492 \\
\hline Responsiveness & 0.652 \\
\hline Assurance & 0.578 \\
\hline Empathy & 0.690 \\
\hline Efficiency & 0.480 \\
\hline Accuracy & 0.627 \\
\hline Security & 0.780 \\
\hline
\end{tabular}

Table No: 5 Area Under the curve

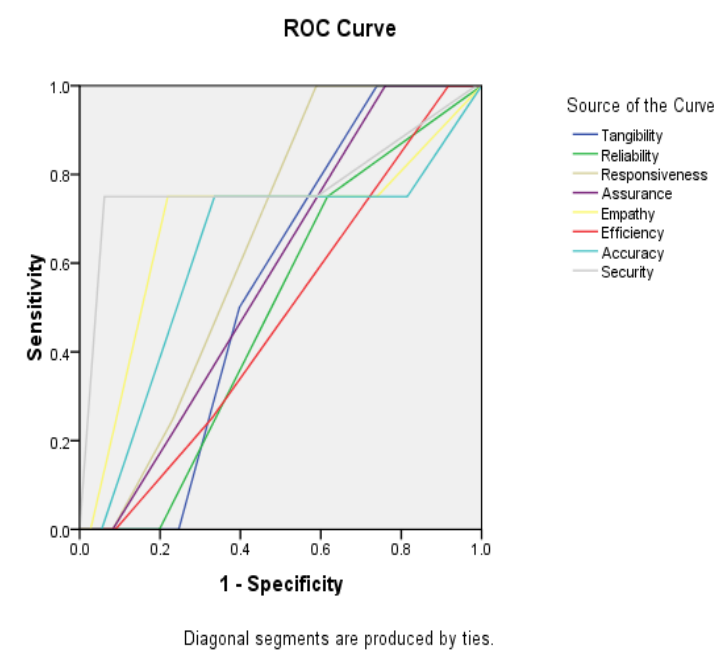

Figure No: 3 ROC Analysis

A service quality is measured by the instrument by considering the likert scale. It has 5 dimensions: tangibles physical communication, reliability - regular service activity, responsiveness - employee willingness with respect to fast delivery, assurance - staff knowledge and empathy good customer care by staff.

\section{CONCLUSION}

The study result shows that younger age group have higher attitude towards Internet banking than older age group. Technology reputation gives a courting among age and the new technology acceptance. Old people are facing troubles with new technologies and have poor attitudes toward improvements. The customer needs can be solved by new innovative solutions in banking services. In order to improve the bank public image, progressive banking services may be a totally important device in attaining this target, particularly when the firm actively engages in shaping requirements for emerging technology. Banks can use mobile services as a positive aggressive advantage as well as a differentiation strategy with competitors. Banks presenting new services is utilized as an enchantment tool for prospective customers; ultimately, progressive banking services are anticipated to open up a new distribution channel for banks to put in force their multi-channel approach; for generation-companies, they open a brand new channel of revenue.

\section{REFERENCES}

1) Yong, J. K., A multidimensional and hierarchical model of service quality in the participant sport industry. doctoraldiss., The Ohio State University. 2000.

2) A. Palani, P. Y. (2012). A Study On Customer Perception Towards Mobile Banking In Indian Overseas Bank Chennai. International Journal of Marketing and Technology , 2 (4), 262-276.

3) Assael, H. (1981), Consumer Behavior and Marketing Action, 3rd Edition, PWS-Kent Publishing Company, Boston, M. A. 
4) Malhotra, N. (2005), Attitude and affect: new frontiers of research in the $21 \mathrm{st}$ century, Journal of Business Research, Vol. 58, pp. 477-482.

5) Wang, Yun and Heitmeyer, Jeanne (2005), "Consumer Attitude toward US versus Domestic

6) Apparel in Taiwan", International Journal of Consumer Studies, Vol. 30, No. 1, pp. 64-74.

7) Ekinci, Y. and Riley, M. (2003), “An Investigation of Self-concept: Actual and Ideal Self congruence Compared in the Context of Service Evaluation", Journal of Retailing and consumer Services, Vol. 10, pp. 201-14. 